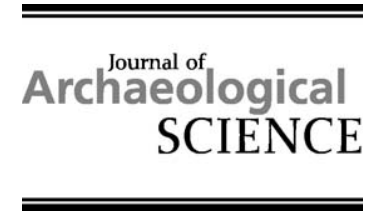

Journal of Archaeological Science 32 (2005) 451-463

http://www.elsevier.com/locate/jas

\title{
Isotopic palaeodiet studies of Ancient Egyptian fauna and humans
}

\author{
Alexandra H. Thompson ${ }^{\mathrm{a}, *}$, Michael P. Richards ${ }^{\mathrm{a}, \mathrm{b}}$, \\ Andrew Shortland ${ }^{\mathrm{c}}$, Sonia R. Zakrzewski ${ }^{\mathrm{d}}$ \\ ${ }^{a}$ Department of Archaeological Sciences, University of Bradford, Bradford, BD7 1DP, UK \\ ${ }^{\mathrm{b}}$ Department of Human Evolution, Max Planck Institute for Evolutionary Anthropology, Deutscher Platz 6, \\ 04103 Leipzig, Germany \\ ${ }^{\mathrm{c}}$ Research Laboratory for Archaeology and the History of Art, University of Oxford, 6 Keble Road, \\ Oxford, OX1 3 OJ, UK \\ ${ }^{\mathrm{d}}$ Department of Archaeology, University of Southampton, Southampton, SO17 1BJ, UK
}

Received 11 February 2004; received in revised form 4 November 2004

\begin{abstract}
We report here stable carbon and nitrogen isotope results from human and faunal bone collagen from samples taken from sites in the Egyptian Nile Valley and surrounding region, dating from the Predynastic (c. 5500 BC) through to the Dynastic (c. 343 BC) periods. Isotopic values for the human population cluster together across this broad time range, with high $\delta^{15} \mathrm{~N}$ ratios, and $\delta^{13} \mathrm{C}$ values indicating a largely $\mathrm{C}_{3}$ based diet. The human data is not easily explained through comparison with our associated faunal data, and so may be explained by the consumption of protein from an ecosystem we did not adequately sample, such as freshwater fish or plants and fauna with unusually high $\delta^{15} \mathrm{~N}$ values due to the extreme aridity of this region. The faunal isotopic data we did produce shows a great range in values between and within species, especially in cattle, and reflects the close proximity of three ecozones across a relatively narrow geographical area; the river, the immediate flood-plain area around the Nile and the desert surroundings.
\end{abstract}

(C) 2004 Elsevier Ltd. All rights reserved.

Keywords: Stable isotopes; Carbon; Nitrogen; Egypt

\section{Introduction}

Egypt is one of the most intensively studied cultures in the world, but the emphasis on the rich textual evidence and mortuary contexts of finds has meant that archaeological sources of evidence relating to everyday food production may have been overlooked until relatively recently. The lack of settlement evidence from Egypt, particularly from earlier periods, is partly due to

\footnotetext{
* Corresponding author.

E-mail address: a.thompson3@bradford.ac.uk (A.H. Thompson).
}

the change in course of the Nile, which has caused the obliteration of many settlement sites that were situated to the east of the river [14]. This is a particular problem when looking at the subsistence economy during the Predynastic and Protodynastic periods, just before and after the formation of the Egyptian State, as detailed written records did not yet exist. Shifts in subsistence patterns accompanied the major social upheaval associated with the period leading up to the formation of a unified state, with a change from a hunter-gatherer mode of subsistence to one increasingly dependent on agriculture [55]. Combined with the limitations associated with archaeobotanical and archaeozoological 
approaches, the lack of textual and settlement evidence has led to comparatively little being known of the development of long-term subsistence patterns in the region.

Looking directly at dietary patterns using the isotopic signatures recorded in the protein component of bone is one way to overcome some of the problems outlined above. There have been a few studies using isotopic analysis of human material from the Nile valley (e.g. $[26,33]$ ), mostly on material from oasis contexts (e.g. [20]) or Nubian material from further to the south in the Nile valley (e.g. [27,60]). None of these studies has included a large sample of faunal remains analysed alongside the human results, which are needed to assist in interpreting the human isotope values. This is likely due to the difficulty in obtaining material for analysis from this region, combined with uncertainties about the contemporaneity of humans and fauna from the same sites. This study presents significant new data on fauna from Egypt, as well as new human isotopic data.

\section{Stable carbon and nitrogen isotope ratios and the foodweb}

The use of stable carbon and nitrogen isotopic ratios in bone collagen is a well-established technique in the investigation of past dietary patterns and subsistence strategies (see recent reviews $[30,34,49]$ ). The basic principle of the technique is that characteristic ratios of stable isotopes can be found between both different foodwebs and their trophic levels due to fractionation effects. This theory has been validated by animal feeding experiments, which have shown that the carbon $\left(\delta^{13} \mathrm{C}\right)$ and nitrogen $\left(\delta^{15} \mathrm{~N}\right)$ isotope composition of collagen mostly reflects that of protein in the diet [3]. Tissues with a slow turnover time such as collagen will therefore contain a long-term record of the diet of the individual, estimated to be that for the last 10-30 years of life [53].

This approach has been used on archaeological human and animal bones in various geographical locations and has provided valuable information regarding not only general diet and subsistence patterns at a population level, but also status and health differences between individuals $[15,39]$, animal management practices [7,43], and palaeoenvironmental data $[6,22]$.

Carbon isotope ratios can give information about the types of plants in the foodweb, in terms of $\mathrm{C}_{3}$ or $\mathrm{C}_{4}$ plants. $\mathrm{C}_{3}$ plants are typically temperate plants, grasses, shrubs and trees, including economically important crops such as wheat and barley, which have average $\delta^{13} \mathrm{C}$ values around $-26 \%$. $\mathrm{C}_{4}$ plants tend to be arid adapted plants and grasses, such as sorghum and millet, with values around $-12 \%$ [46]. Carbon isotope values can also be used to distinguish marine versus terrestrial food sources [40,45], but this is not such a relevant consideration in the inland context of the Nile valley.

Nitrogen isotope values can give information about the trophic level of dietary protein. Schoeninger and DeNiro reported a c. $3 \%$ increase in $\delta^{15} \mathrm{~N}$ value between food and consumer [44], although diet-tissue enrichment as high as $6.5 \%$ in alpaca has been published in a study highlighting inter-species differences in ${ }^{15} \mathrm{~N}$ enrichment [52]. However, recent research has indicated that it is more appropriate to use a range of $3-5 \%$ for $\delta^{15} \mathrm{~N}$ enrichment than an average value [8]. The longer length of aquatic food chains compared to terrestrial ones means that higher $\delta^{15} \mathrm{~N}$ values can also indicate consumption of aquatic resources [18]. An arid environment may also produce high $\delta^{15} \mathrm{~N}$ values, thought to be due to the effects of water and heat stress on urinary nitrogen excretion and/or protein stress causing tissues to become ${ }^{15} \mathrm{~N}$-enriched, or to an increase in the evaporation of isotopically light ammonia from the soil where rainfall is low $[2,24,25,47,50]$. In an ecological context with sharp distinctions, such as between the Nile valley and the surrounding desert, it may therefore be possible to distinguish valley and desert consumers.

\section{Textual and archaeological evidence for diet in Egypt}

There is a wealth of information regarding food resources in Dynastic Egypt, mostly derived from an art-historical perspective by examining sources such as tomb paintings (e.g. [16,23]). Modern excavations where archaeozoological and archaeobotanical analyses are routinely undertaken have also provided more direct evidence of the dietary resources which were available to people [31]. This evidence only indicates what resources were available however, and their presence at a site may be for a number of reasons. Stable isotope analysis can therefore provide a direct measure of the broad categories of foods that were actually exploited.

Agriculture appeared in Egypt on a large scale at about $5000 \mathrm{BC}$, with the earliest evidence coming from the Fayum region. Initially a wholesale adoption appears not to have taken place, rather an incorporation into an efficient wider strategy of gathering and hunting in the relatively wetter, milder savannah-like conditions prevailing at the time [54]. A major climate shift causing wider desertification in the region seems to have forced people into the Nile valley at about 3500 BC [14]. This narrowed the dietary resources available as big game animals, previously widely available in the region, dwindled until they eventually disappeared. Agriculture became the main mode of subsistence in the Nile valley around the same time as the process of state formation was just beginning. 
The broad picture of diet in Egypt produced from traditional sources indicates a base of $\mathrm{C}_{3}$ plant resources, largely in the form of the staple foods of bread and beer produced from emmer wheat and barley grown in the Nile valley. Archaeological evidence for this comes from the discoveries of closely associated bakeries and breweries, which had brewing vats and pottery bread baking moulds [14]. Textual evidence also attests to the ubiquitous consumption of these goods and their underpinning of the economic system, with taxation and wages for those working for the state being paid in bread and beer rations [37]. A wide range of vegetables were also available, which could be easily grown on the fertile floodplains of the Nile, renewed annually by the inundation, the key event in the Egyptian year which made agriculture in the Nile Valley so productive $[37,62]$.

The Nile was also a key resource in providing wild sources of protein available to most inhabitants in the form of fish and other riverine species such as softshelled turtle. Wild animal resources from the desert margin in Dynastic Egypt were scarce due to the arid environment making the support of large animals impossible [14]. Animals kept for consumption commonly included goats, sheep and pigs, whilst dairy products were supplied by ovicaprids and cattle [28]. Cattle were not generally eaten by the majority of the population, being kept as dairy and draught animals and also having a certain status attached to them as part of religious cults such as the Apis bull cult and that of the cow-headed goddess Hathor.

\section{Stable isotope evidence for diet in Egypt}

Previous studies undertaken on human material from the Nile Valley and desert oases have generally indicated a diet mainly based upon $\mathrm{C}_{3}$ plant resources in Egypt, with heavier dependence on $\mathrm{C}_{4}$ plants in Nubia (see Table 1). Bone material, hair and skin have all been analysed and although these values from different tissues are not directly comparable, they do give valuable information on long- and short-term diet.

Results from four isotopic studies on material from Egyptian oases have been published, three from the Dakhleh Oasis [19,20,47] and one from the Kharga Oasis [61]. Both of the Dakhleh Oasis studies concentrated on later periods in Egyptian history, namely the Late Ptolemaic period (c. 50 BC) [47] and the Roman period $[19,20]$. All studies report humans with both elevated $\delta^{15} \mathrm{~N}$ values and $\delta^{13} \mathrm{C}$ values indicative of a $\mathrm{C}_{3^{-}}$ based diet. The study by Dupras et al. [20] also provided some faunal isotopic values, showing a range of $\delta^{13} \mathrm{C}$ values that indicated a diet of mixed $\mathrm{C}_{3}$ and $\mathrm{C}_{4}$ components. $\delta^{13} \mathrm{C}$ values of the mummified human remains from Kharga Oasis, ranging in date from the 25th Dynasty to the Coptic period, also indicated a diet based upon $\mathrm{C}_{3}$ plant sources [61].

Human material from a Nile Valley context has been analysed in three studies, the first used bone collagen [26] and the other two used hair [33,61]. Iacumin et al. [26] studied material dating from the Predynastic period and the First Intermediate Period, and found generally lower $\delta^{15} \mathrm{~N}$ values than seen in the oasis studies, together with a dependence upon a $\mathrm{C}_{3}$ dietary base and freshwater fish resources. This study found little change in isotopic values through time. The other two studies analysed hair from Late Middle Kingdom mummies and Roman-Byzantine individuals from Wadi Halfa indicated a very similar dietary pattern.

More work has been carried out on material from Nubia examining carbon and nitrogen isotopic ratios in bone collagen, skin and hair $[27,48,57,58,60]$ as well as oxygen isotope ratios [56]. The results indicate a large $\mathrm{C}_{4}$ input to the diet in Nubia during a period contemporaneous with the Egyptian Middle Kingdom. However, the increasingly negative $\delta^{13} \mathrm{C}$ values through time suggested a progressive increase in $\mathrm{C}_{3}$ input [27]. Seasonality in the exploitation of $\mathrm{C}_{3}$ plants during the wet season after the innundation and $\mathrm{C}_{4}$ plants during drier spells was also reported [48,57]. Elevated $\delta^{15} \mathrm{~N}$ values were found, and interpreted as being due to environmental influences and/or a dependence on Nile fish resources.

\section{Materials and methods}

\subsection{Human samples}

The human samples $(n=55)$ were obtained from a variety of sites (see Table 2, Fig. 1) and time periods, and all are from mortuary contexts. They were mostly excavated in the nineteenth century, ranging in date from the Predynastic period (c. 5500-3100 BC) to the 26-30th Dynasties (664-343 BC). The material is currently held in the Duckworth Collection, University of Cambridge.

Material from the Predynastic period sites, dating to c. 5500-3100 BC, of Naqada (excavated by Petrie and Quibell in the 1890s), Hierakonpolis (excavated by Brunton and De Morgan in the 1880s) and el-Badari (excavated by Brunton and Caton-Thompson in the 1920s onwards) was sampled. All of the graves were dated using the pottery seriation system devised by Petrie, which has formed the basis of Predynastic period Egyptian chronologies. Material from 1st Dynasty (c. 3100-2890 BC) and 12th Dynasty (c. 1991-1786 BC) Abydos (excavated by Petrie in the 1890 s to early 1900s) was also included. Later remains originate from further north, from cemeteries of 18th Dynasty Saqqara (c. 1567-1320 BC), 21st Dynasty Qurneh (c. 1089-945 BC) 
Table 1

Isotopic data from previous Nile Valley and Oasis studies

\begin{tabular}{|c|c|c|c|c|c|c|}
\hline Sample & Site & Age & $\delta^{13} \mathrm{C}$ & $\mathrm{SD} \delta^{13} \mathrm{C}$ & $\delta^{15} \mathrm{~N}$ & $\mathrm{SD} \delta^{15} \mathrm{~N}$ \\
\hline \multicolumn{7}{|c|}{ Egyptian humans } \\
\hline Bone & Gebelein $(n=3)^{4}$ & Predynastic (6950-4950 BP) & -19.4 & 0.2 & 12.2 & 1 \\
\hline Bone & Gebelein $(n=6)^{4}$ & 1st Intermediate period (4120-3990 BP) & -19.4 & 0.3 & 12.9 & 0.9 \\
\hline Bone & Asyut $(n=8)^{4}$ & 1st Intermediate period (4120-3990 BP) & -19.8 & 0.4 & 13 & 1 \\
\hline Hair & Unknown $(n=9)^{5}$ & Late Middle Kingdom mummies & -21.5 & 1.1 & 14 & 1.1 \\
\hline Skin & Kharga Oasis $(n=4)^{3}$ & 25th Dynasty - Coptic period & -20.43 & 0.55 & 1 & / \\
\hline Hair & Kharga Oasis $(n=22)^{3}$ & 25th Dynasty - Coptic period & -19.6 & 0.5 & / & / \\
\hline Bone & Dakhleh Oasis $(n=25)^{1}$ & Late Ptolemaic - Christian period & / & / & 17.6 & 1.5 \\
\hline Bone & Dakhleh Oasis $(n=32)^{2}$ & Romano-Christian period & 1 & / & 17.9 & 1.1 \\
\hline \multicolumn{7}{|l|}{ Nubian humans } \\
\hline Bone & Kerma Necropolis, Nubia $(n=5)^{6}$ & Ancient Kerma (2450-2000 BC) & -16.3 & 1.3 & 12.2 & 0.8 \\
\hline Bone & Kerma Necropolis, Nubia $(n=4)^{6}$ & Middle Kerma (2000-1700 BC) & -19.7 & 1 & 13 & 1 \\
\hline Bone & Kerma Necropolis, Nubia $(n=2)^{6}$ & Classic Kerma (1700-1450 BC) & -20.3 & 3.8 & 12 & 2.2 \\
\hline Bone & Wadi Haifa $(n=31)^{7}$ & Meriotic period (350 BC - AD 350) & -18.1 & 1 & 12.3 & 1.1 \\
\hline Bone & Unknown $^{8}$ & X-Group period (AD $350-$ AD 550) & -16.9 & 0.7 & 11.1 & 1.2 \\
\hline Bone & Wadi Haifa $(n=35)^{7}$ & X-Group period (AD 350 - AD 550) & -17 & 0.8 & 11.1 & 1.1 \\
\hline Bone & Wadi Haifa $(n=24)^{7}$ & Christian period (AD $500-$ AD 1400) & -18.7 & 1.6 & 10.6 & 1.2 \\
\hline \multicolumn{7}{|l|}{ Faunal } \\
\hline Pig bone & Dakhlek Oasis $^{2}$ & Romano-Christian period & -17.4 & / & 13.3 & / \\
\hline Chicken bone & Dakhlek Oasis ${ }^{2}$ & Romano-Christian period & -18.4 & 1 & 16.2 & 1 \\
\hline Gazelle bone & Dakhlek Oasis ${ }^{2}$ & Romano-Christian period & -17.9 & 1 & 13.2 & / \\
\hline Cow bone & Dakhlek Oasis ${ }^{2}$ & Romano-Christian period & -15.1 & / & 13.1 & / \\
\hline Goat bone & Dakhlek Oasis ${ }^{2}$ & Romano-Christian period & -15.7 & / & 13.4 & / \\
\hline Ox bone & Unknown provenance $(n=1)^{4}$ & 18th Dynasty & -23.2 & 1 & 9.4 & / \\
\hline Goat bone & Kerma Necropolis $(n=1)^{6}$ & Middle Kerma (4000-3700 BP) & -22.7 & / & 6.7 & / \\
\hline Goat bone & Kerma Necropolis $(n=1)^{6}$ & Classic Kerma (3700-3450 BP) & -11 & / & 11.2 & / \\
\hline
\end{tabular}

(1) Schwarcz et al. [47:633]; (2) Dupras et al. [20:210, Table 2]; (3) White et al. [59:7-8]; (4) Iacumin et al. [26:118, Table 2; 120, Table 4]; (5) Macko et al. [33:72, Fig. 8]; (6) Iacumin et al. [27:295, Table 1; 296, Table 2]; (7) White and Schwarcz [58:Table 7]; (8) White and Armelagos [60:Table 1].

and 26-30th Dynasty Gizeh (c. 662-343 BC). Although some individuals have been sexed, nothing is known of the grave goods found in the burials, so unfortunately it is not possible to use that information to infer the status of individuals.

\subsection{Faunal samples}

The faunal samples $(n=65)$ mostly originate from the sites of el-Badari and Mostagedda, although some are unprovenanced samples from Petrie's collections (see Table 3). Despite the unknown origin of some of this material within Egypt, it was decided to include it, as there are very few faunal samples available from Egypt for isotopic analysis. The material from el-Badari comes from the excavations of Caton-Thompson in the 1920s and dates to the Late Old Kingdom [12] and that from Mostagedda from Brunton's excavations also in the 1920s. The cattle remains from el-Badari and Mostagedda are documented in excavation reports as having been donated to the Natural History Museum's collection [13,12]). The el-Badari oxen burials were stratigraphically dated to the Late Old Kingdom (c. 2000 BC) and those from Mostagedda to the Badarian period (c. $4000 \mathrm{BC}$ ), found during the excavation of debris pits from the village. Some of the samples originate from Qau, close to el-Badari, and Lahun, although unfortunately it was not possible to identify them in the excavation reports and date them. The hartebeest samples are from further north at Hawara in the Fayum and four other bos samples are from Kharga Oasis.

In total, bone samples were obtained from 55 humans, 40 cattle (13 domestic Bos taurus and 27 only identified as $B o s$ ), 1 unidentified bovid, 8 ovicaprids (4 sheep, 4 sheep/goat), 4 pigs, 2 hyena, 2 buffalo, 2 hartebeest, 2 equids, 2 dogs, 1 camel and 1 Nile Perch. Approximately $1 \mathrm{~g}$ of whole bone was sampled and then the outer surface of each sample was removed using an air-abrasion machine. Approximately $500 \mathrm{mg}$ of bone was then weighed and demineralised in a $0.5 \mathrm{M} \mathrm{HCl}$ solution at $4{ }^{\circ} \mathrm{C}$. Samples were then rinsed in deionised water three times and gelatinised at $70{ }^{\circ} \mathrm{C}$ in a pH 3 solution for $48 \mathrm{~h}$. The gelatin portion of the resulting solution was isolated by filtration through an $8 \mu \mathrm{m}$ filter and then through a $30 \mathrm{kDa}$ filter, to remove molecular contaminants [11]. The resultant residue was freezedried for $48 \mathrm{~h}$ and then $0.3-0.5 \mathrm{mg}$ aliquots were weighed out into tin capsules for subsequent isotopic measurement. Duplicates of each sample were prepared for analysis, except in cases of exceptionally low yield. Isotopic values were determined at the Stable Isotope 
Table 2

Isotopic measurements on collagen extracted from human bone samples

\begin{tabular}{|c|c|c|c|c|c|c|c|c|}
\hline Site & Sample number & Period & $\delta^{13} \mathrm{C}$ & $\delta^{15} \mathrm{~N}$ & $\mathrm{C}: \mathrm{N}$ & $\%$ Collagen & $\% \mathrm{C}$ & $\% \mathrm{~N}$ \\
\hline el-Badari & E54 & Predynastic & -18.9 & 12.5 & 4.4 & 3.0 & 15.8 & 4.2 \\
\hline el-Badari & E53 & Predynastic & / & 1 & 3.3 & 0.5 & 1.7 & 0.6 \\
\hline el-Badari & E52 & Predynastic & 1 & 1 & 5.2 & 0.1 & 1.0 & 0.2 \\
\hline el-Badari & E51 & Predynastic & -17.5 & 12.7 & 5.9 & 0.2 & 3.6 & 0.7 \\
\hline el-Badari & E50 & Predynastic & 1 & 1 & 12.3 & 0.4 & 9.7 & 0.9 \\
\hline el-Badari & E49 & Predynastic & -18.9 & 12.7 & 3.5 & 1.9 & 30.3 & 10.3 \\
\hline el-Badari & E28 & Predynastic & -19.0 & 13.0 & 3.4 & 3.1 & 40.4 & 14.1 \\
\hline el-Badari & $\mathbf{E 4 2}$ & Predynastic & -19.7 & 12.2 & 3.3 & 1.9 & 36.4 & 12.9 \\
\hline Naqada & E48 & Predynastic & 1 & 1 & I & 0.0 & 1 & 1 \\
\hline Naqada & E46 & Predynastic & I & / & / & 0.0 & / & 1 \\
\hline Naqada & E47 & Predynastic & 1 & 1 & 4.0 & 0.2 & 2.2 & 0.7 \\
\hline Naqada & E32* & Predynastic & -18.5 & 12.5 & 3.3 & 2.6 & 39.6 & 13.8 \\
\hline Naqada & E30 & Predynastic & 1 & 1 & 1 & 0.0 & 1 & 1 \\
\hline Naqada & E34* & Predynastic & -18.6 & 10.7 & 3.4 & 1.6 & 37.8 & 13.0 \\
\hline Naqada & E31* & Predynastic & -18.7 & 13.3 & 3.3 & 2.9 & 43.6 & 15.3 \\
\hline Naqada & E44 & Predynastic & -19.0 & 13.5 & 3.5 & 0.6 & 9.1 & 3.0 \\
\hline Hierakonpolis & E1 & Predynastic & 1 & 1 & 1 & 0.0 & 1 & 1 \\
\hline Hierakonpolis & E3 & Predynastic & 1 & 1 & 1 & 0.1 & 1 & 1 \\
\hline Hierakonpolis & E45 & Predynastic & -19.5 & 14.0 & 4.1 & 0.6 & 3.9 & 1.1 \\
\hline Hierakonpolis & E41 & Predynastic & -18.9 & 13.1 & 4.1 & 0.5 & 4.2 & 1.2 \\
\hline Hierakonpolis & E42 & Predynastic & 1 & 1 & 1 & 0.0 & 1 & 1 \\
\hline Hierakonpolis & $\mathbf{E 4 3}$ & Predynastic & -20.8 & 13.4 & 3.4 & 0.2 & 38.5 & 13.5 \\
\hline Hierakonpolis & E40 & Predynastic & 1 & 1 & 1 & 0.0 & 1 & 1 \\
\hline Abydos & E38 & 1st Dynasty & i & i & 1 & 0.0 & i & i \\
\hline Abydos & E39 & 1st Dynasty & 1 & 1 & 1 & 0.0 & 1 & 1 \\
\hline Abydos & E6 & 1st Dynasty & 1 & / & 1 & 0.0 & / & 1 \\
\hline Abydos & E5 & 1st Dynasty & -21.5 & 12.1 & 6.9 & 0.2 & 4.7 & 0.8 \\
\hline Abydos & E2 & 1st Dynasty & 1 & 1 & 1 & 0.0 & 1 & 1 \\
\hline Abydos & E17 & 1st Dynasty & 1 & 1 & 1 & 0.0 & 1 & I \\
\hline Abydos & E16 & 1st Dynasty & -20.2 & 12.0 & 6.9 & 0.4 & 5.3 & 0.9 \\
\hline Abydos & E11 & 1st Dynasty & -25.0 & 12.0 & 9.2 & 0.3 & 19.0 & 2.4 \\
\hline Abydos & E37 & 1st Dynasty & 1 & 1 & 1 & 0.0 & 1 & 1 \\
\hline Abydos & E10 & 1st Dynasty & i & i & 1 & 0.0 & i & i \\
\hline Qau & E12 & 6th Dynasty & i & 1 & i & 0.0 & 1 & i \\
\hline Qau & E26 & 6th Dynasty & 1 & / & 1 & 0.1 & I & 1 \\
\hline Qau & E27 & 6th Dynasty & -20.9 & 12.7 & 3.9 & 0.4 & 71.6 & 21.5 \\
\hline Qau & E28 & 6th Dynasty & 1 & 1 & 1 & 1 & 1 & 1 \\
\hline Qau & E25 & 6th Dynasty & 1 & 1 & 1 & 0.0 & 1 & 1 \\
\hline Abydos & $\mathbf{E 4}$ & 12th Dynasty & -18.5 & 13.6 & 3.4 & 4.7 & 41.7 & 14.5 \\
\hline Abydos & E36 & 12th Dynasty & -18.4 & 12.4 & 3.4 & 0.2 & 28.9 & 10.1 \\
\hline Abydos & E29 & 12th Dynasty & -19.9 & 13.0 & 4.4 & 0.2 & 16.4 & 4.4 \\
\hline Abydos & E35 & 12th Dynasty & -19.4 & 13.4 & 3.7 & 3.9 & 34.3 & 10.7 \\
\hline Saqqara & E24 & 18th Dynasty & 1 & 1 & 1 & 0.0 & / & / \\
\hline Saqqara & E13 & 18th Dynasty & -20.9 & 12.7 & 5.8 & 2.9 & 40.1 & 8.1 \\
\hline Qurneh & E7 & 21st Dynasty & -21.1 & 13.8 & 6.8 & 6.6 & 49.7 & 8.5 \\
\hline Qurneh & E8 & 21st Dynasty & 1 & 1 & 1 & 0.0 & 1 & 1 \\
\hline Qurneh & E9 & 21 st Dynasty & 1 & 1 & 1 & 0.0 & 1 & 1 \\
\hline Gizeh & $\mathbf{E 2 3}$ & 26-30th Dynasty & -19.0 & 13.5 & 3.5 & 0.7 & 51.3 & 17.1 \\
\hline Gizeh & E22 & 26-30th Dynasty & 1 & 1 & 1 & 0.0 & 1 & 1 \\
\hline Gizeh & E21 & 26-30th Dynasty & -19.1 & 14.8 & 3.3 & 3.6 & 46.3 & 16.6 \\
\hline Gizeh & E20 & 26-30th Dynasty & 1 & 1 & 1 & 0.0 & 1 & 1 \\
\hline Gizeh & E18 & 26-30th Dynasty & -19.3 & 13.1 & 3.5 & 0.1 & 36.7 & 12.2 \\
\hline Gizeh & E15 & 26-30th Dynasty & -18.8 & 14.6 & 3.4 & 9.6 & 48.5 & 16.7 \\
\hline Gizeh & E19 & 26-30th Dynasty & -19.9 & 13.3 & 3.3 & 5.2 & 17.5 & 6.2 \\
\hline Gizeh & E14 & 26-30th Dynasty & -20.1 & 14.2 & 3.2 & 2.7 & 30.1 & 11.0 \\
\hline
\end{tabular}

Acceptable samples based on $\mathrm{C}: \mathrm{N}$ ratio and $\% \mathrm{C}, \% \mathrm{~N}$ in bold. ${ }^{*}$ Denotes samples treated with PVA.

Laboratory, Department of Archaeological Science, University of Bradford, UK. Isotope values were determined by continuous flow isotope ratio mass spectrometry, using either a Europa Roboprep elemen- tal analyser coupled to a Europa 20/20 isotope ratio mass spectrometer, or a Carlo-Erba elemental analyser coupled to a Thermo Finnigan Delta Plus XL isotope ratio mass spectrometer. The analytical error for $\delta^{13} \mathrm{C}$ 


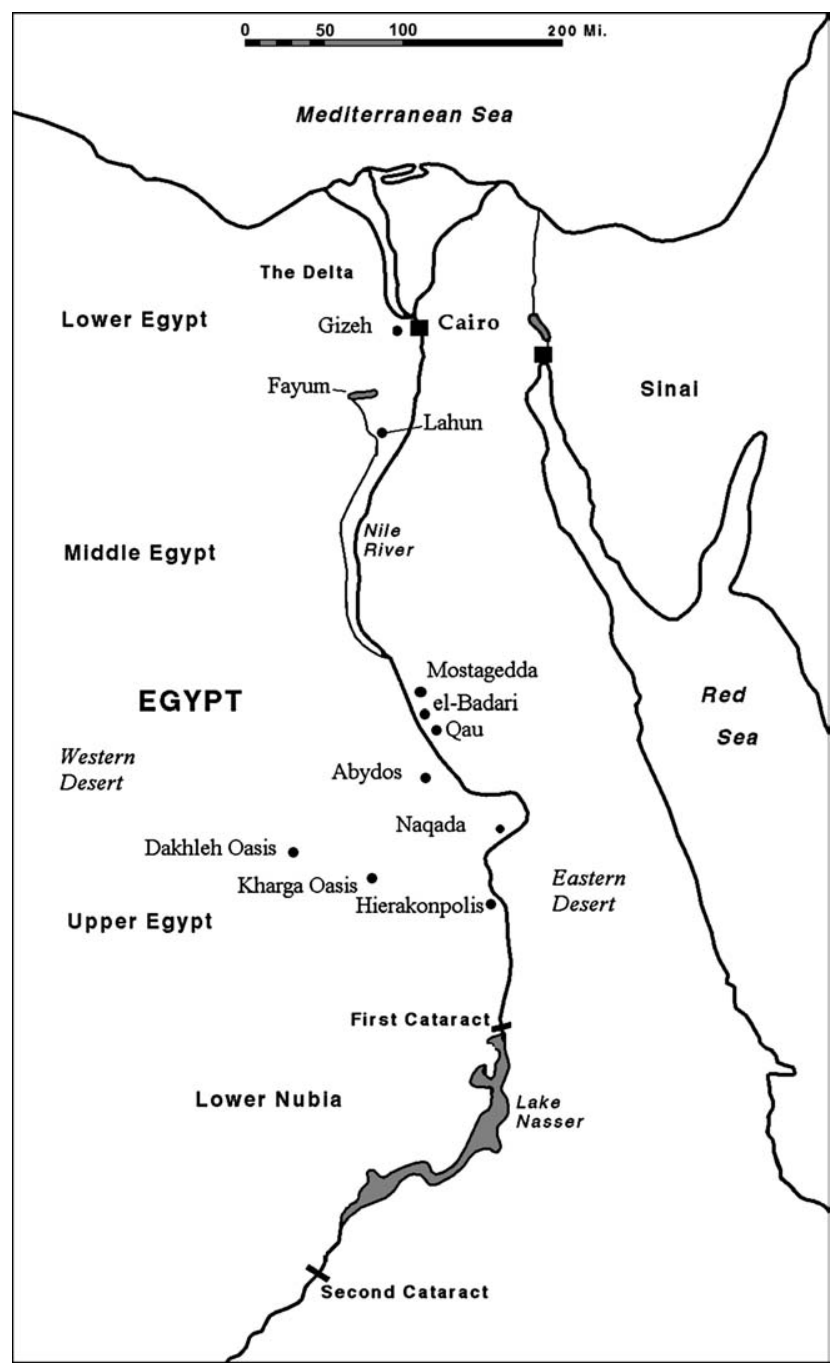

Fig. 1. Map of Egypt, showing the locations of the sites from which isotope data are presented.

and $\delta^{15} \mathrm{~N}$ is $\pm 0.2 \%$ for both machines, based upon reproducibility of internal and international standards.

Some of the faunal samples had been treated with PVA (polyvinyl acetate), a consolidant used during conservation. This was removed before demineralisation by soaking in acetone for $2 \mathrm{~h}$ at $50{ }^{\circ} \mathrm{C}$ in a heater block [35]. The acetone was then changed and the samples left at room temperature overnight, after which the acetone was removed and the samples were washed 3 times with deionised water. The ultrafiltration step also helps remove PVA.

\section{Results and discussion}

\subsection{Sample preservation}

The C:N ratios for the "collagen" produced were used to ascertain its state of preservation, with accept- able samples having values between 2.9 and 3.6, the range of values seen in modern bone [17]. Samples with values outside this range are rejected on the basis that the collagen has undergone postmortem diagenesis which has either introduced or removed carbon and/or nitrogen. The percentage of carbon and nitrogen present in the samples can also be used as criteria to assess preservation, with "well-preserved bone" being expected to have concentrations of above $13.0 \%$ and $4.8 \%$ respectively [1]. We found relatively low yields of collagen, often less than $1 \%$, as we might expect in samples from a hot and arid environment. Our low yield is also due to the use of ultrafiltration to remove any fragments less than $30 \mathrm{kDa}$. This ultrafiltration step helps purify the collagen, and therefore we believe that the samples with low yields but acceptable $\mathrm{C}: \mathrm{N}$ and $\% \mathrm{C}$ and $\% \mathrm{~N}$ yields are still intact collagen, and the isotopic values produced from them are valid.

The faunal material generally appears to have better collagen preservation than the human samples. A possible explanation for this is the possibility that the animal bones may have been deposited in a disarticulated and/or defleshed state (i.e. as offerings), whilst humans were interred intact and their gut flora and fauna could have contributed to the decomposition of proteins in the human bones. As discussed above for the faunal samples, the hot, arid environment from which the samples originate is the primary cause of the low collagen yields, as this will have broken down biological molecules such as collagen causing a high "thermal aging" effect [51]. The overall success rate for successful collagen extraction for human samples was approximately $25 \%$, and was approximately $50 \%$ for faunal samples.

\subsection{Faunal samples (Table 3, figures $2 \& 4$ )}

The isotopic values of the faunal samples are remarkably varied, indicating the consumption of both $\mathrm{C}_{3}$ (i.e. plant resources from the Nile Valley) and $\mathrm{C}_{4}$ plants (i.e. desert margin plants and grasses) (Table 3, Figs. 24). When the isotopic measurements are plotted, it can be seen that many individuals show elevated $\delta^{15} \mathrm{~N}$ values compared to typical values from a temperate environment, where, for example, cattle have $\delta^{15} \mathrm{~N}$ values of approximately $4-6 \%[5,41]$. This is a commonly observed phenomenon in desert environments, and as discussed above is due to either enriched soil and therefore plant values due to evaporation of "light" nitrogen isotopes from the soil [47], or a physiological phenomenon where lack of water in a hot environment causes metabolic changes to urea excretion, leading to ${ }^{15} \mathrm{~N}$ enrichment of body tissues. The latter explanation is less likely, especially as recent research reported that there were no significant physiological or metabolic 
Table 3

Isotopic data from collagen extracted from faunal samples (acceptable samples in bold based on $\mathrm{C}: \mathrm{N}$ and $\% \mathrm{C} \% \mathrm{~N}$, ${ }^{*}$ denotes samples treated with PVA)

\begin{tabular}{|c|c|c|c|c|c|c|c|}
\hline Site & Species & $\delta^{13} \mathrm{C}$ & $\delta^{15} \mathrm{~N}$ & $\mathrm{C}: \mathrm{N}$ & $\%$ Collagen & $\% \mathrm{C}$ & $\% \mathrm{~N}$ \\
\hline Mostagedda & Sheep (Ovis aries) & -15.9 & 9.3 & 3.2 & 7.7 & 42.7 & 15.9 \\
\hline Mostagedda & Sheep (Ovis aries) ${ }^{*}$ & / & / & / & 0.0 & / & / \\
\hline Mostagedda & Goat (Capra hircus) & -17.5 & 10.7 & 3.6 & 9.4 & 43.3 & 14.0 \\
\hline Mostagedda & Cow (Bos taurus) & -12.7 & 9.1 & 3.1 & 5.1 & 32.1 & 12.1 \\
\hline Mostagedda & Cow (Bos spp.) & -13.7 & 9.3 & 3.2 & 4.2 & 24.9 & 9.1 \\
\hline Mostagedda & Cow (Bos spp.) & / & / & 1 & 0.0 & 1 & 1 \\
\hline Mostagedda & Sheep (Ovis aries) ${ }^{*}$ & -18.9 & 6.6 & 3.2 & 2.4 & 35.2 & 11.6 \\
\hline Mostagedda & Cow (Bos taurus) & -19.0 & 9.4 & 3.1 & 9.7 & 31.3 & 11.7 \\
\hline Mostagedda & Cow (Bos spp.)* & -15.7 & 10.7 & 3.6 & 0.2 & 18.2 & 6.0 \\
\hline Mostagedda & Pig (Sus scrofa) & -20.9 & 7.8 & 3.1 & 11.5 & 32.8 & 12.2 \\
\hline Mostagedda & Equid (Equus spp.) & -20.5 & 4.3 & 3.1 & 8.5 & 30.9 & 11.7 \\
\hline Mostagedda & Striped Hyena (Hyaena hyaena) & -14.1 & 12.9 & 3.1 & 9.5 & 42.9 & 16.2 \\
\hline Mostagedda & Bovid (Bovidae spp.) & -19.9 & 7.9 & 3.1 & 0.7 & / & 1 \\
\hline Mostagedda & Camel (Camelus dromedaries) & -12.3 & 11.7 & 3.1 & 6.9 & 42.7 & 16.0 \\
\hline el-Badari & Sheep/Goat (Ovis aries/Capra hircus) & -18.9 & 6.8 & 3.2 & 0.3 & 46.6 & 17.2 \\
\hline el-Badari & Sheep/Goat (Ovis aries/Capra hircus) & / & / & / & 0.1 & / & l \\
\hline el-Badari & Sheep/Goat (Ovis aries/Capra hircus) & / & / & / & 0.1 & 1 & l \\
\hline el-Badari & Sheep/Goat (Ovis aries/Capra hircus) & 1 & 1 & 1 & 1.4 & 1 & 1 \\
\hline el-Badari & Cow (Bos taurus) & -15.8 & 9.5 & 3.5 & 12.4 & l & l \\
\hline el-Badari & Cow (Bos taurus) & -17.1 & 10.0 & 3.9 & 10.6 & l & 1 \\
\hline el-Badari & Cow (Bos taurus) & -18.9 & 6.8 & 3.2 & 0.8 & 33.1 & 12.2 \\
\hline el-Badari & Cow (Bos taurus) & / & 1 & 1 & 0.1 & / & / \\
\hline el-Badari & Cow (Bos taurus) & -13.1 & 12.0 & 3.2 & 6.6 & 29.9 & 10.8 \\
\hline el-Badari & Cow (Bos taurus) & -17.2 & 11.5 & 3.2 & 4.1 & 31.3 & 11.3 \\
\hline el-Badari & Cow (Bos taurus) & -16.3 & 11.5 & 3.2 & 2.8 & 32.2 & 11.7 \\
\hline el-Badari & Cow (Bos taurus) & -12.5 & 12.9 & 3.2 & 8.2 & 23.6 & 8.6 \\
\hline el-Badari & Cow (Bos taurus) & -13.1 & 11.6 & 3.2 & 2.2 & 30.5 & 11.2 \\
\hline el-Badari & Cow (Bos taurus) & -15.9 & 11.1 & 3.2 & 1.8 & 28.6 & 10.4 \\
\hline el-Badari & Ass (Equus anisus) & / & / & 1 & 0.2 & / & / \\
\hline el-Badari & Pig (Sus scrofa) & / & / & / & 0.1 & / & / \\
\hline el-Badari & Pig (Sus scrofa) & -17.6 & 9.7 & 3.2 & 5.4 & 18.1 & 6.6 \\
\hline Unknown (Petrie Collection) & Cow (Bos spp.) & -11.2 & 11.6 & 3.3 & 2.1 & 39.7 & 14.2 \\
\hline Unknown (Petrie Collection) & Ass (Equus asinus) & -16.8 & 12.9 & 3.1 & 0.2 & 59.6 & 22.7 \\
\hline Unknown (Petrie Collection) & Cow (Bos spp.) & / & / & 1 & 0.1 & l & l \\
\hline Unknown (Petrie Collection) & Cow (Bos spp.) $)^{*}$ & i & / & / & 0.6 & 1 & i \\
\hline Unknown (Petrie Collection) & Cow (Bos spp.) ${ }^{*}$ & / & / & / & 0.8 & l & l \\
\hline Unknown (Petrie Collection) & Cow $(\text { Bos spp. })^{*}$ & / & / & 1 & 0.0 & i & 1 \\
\hline Unknown (Petrie Collection) & East African Buffalo (Syncerus caffer) & -19.9 & 7.7 & 3.3 & 0.2 & 46.7 & 16.5 \\
\hline Unknown (Petrie Collection) & East African Buffalo (Syncerus caffer) & / & / & 1 & 0.0 & / & / \\
\hline Unknown (Petrie Collection) & Cow (Bos spp.) & / & / & / & 0.0 & i & / \\
\hline Unknown (Petrie Collection) & Cow (Bos spp.) & / & 1 & / & 0.1 & 1 & 1 \\
\hline Unknown (Petrie Collection) & Cow (Bos spp.) & i & 1 & / & 0.1 & i & 1 \\
\hline Unknown (Petrie Collection) & Cow (Bos spp.) & / & / & / & 0.1 & 1 & / \\
\hline Unknown (Petrie Collection) & Cow (Bos spp.) & 1 & / & l & 0.1 & 1 & / \\
\hline Unknown (Petrie Collection) & Cow (Bos spp.) & / & / & i & 0.4 & / & / \\
\hline Lahun & Cow (Bos spp.) & / & / & 1 & 0.3 & 1 & / \\
\hline Lahun & Cow (Bos spp.) & i & / & / & 0.6 & 1 & / \\
\hline Unknown (Petrie Collection) & Cow (Bos spp.) & -26.5 & / & 4.8 & 0.2 & 86.4 & 21.2 \\
\hline Unknown (Petrie Collection) & Cow (Bos spp.) & -19.0 & 5.3 & 5.0 & 1.8 & 6.8 & 1.6 \\
\hline Unknown (Petrie Collection) & Turtle (Testudinidae) & / & 1 & / & 0.1 & l & 1 \\
\hline Unknown (Petrie Collection) & Cow (Bos taurus) & -14.0 & 4.4 & 3.1 & 0.1 & 55.7 & 20.7 \\
\hline Unknown (Petrie Collection) & Hartebeest (Alceleophus bucelaphus)" & -16.2 & 15.6 & 3.2 & 5.6 & 43.7 & 16.2 \\
\hline Unknown (Petrie Collection) & Hartebeest (Alceleophus bucelaphus)" & $-\mathbf{1 7 . 0}$ & 12.3 & 3.1 & 8.0 & 42.6 & 15.9 \\
\hline Unknown (Petrie Collection) & Nile Perch (Lates niloticus) & -14.9 & 5.0 & 3.5 & 3.0 & 42.0 & 13.9 \\
\hline Kharga Oasis & Pig (Sus spp.) & / & / & / & 0.2 & / & / \\
\hline Kharga Oasis & Cow (Bos spp.) & / & / & 1 & 0.1 & 1 & 1 \\
\hline Kharga Oasis & Cow (Bos spp.) & -8.9 & 10.7 & 3.2 & 1.0 & 41.7 & 15.4 \\
\hline Kharga Oasis & Cow (Bos spp.) & / & / & 1 & 0.0 & / & / \\
\hline Mostagedda & Sheep (Ovis aries) & -15.9 & 9.3 & 3.2 & 7.7 & 42.7 & 15.9 \\
\hline Mostagedda & Sheep (Ovis aries) ${ }^{*}$ & / & / & 1 & 0.0 & / & 1 \\
\hline Mostagedda & Cow (Bos taurus) & -12.7 & 9.1 & 3.1 & 5.1 & 32.1 & 12.1 \\
\hline
\end{tabular}


Table 3 (continued)

\begin{tabular}{|c|c|c|c|c|c|c|c|}
\hline Site & Species & $\delta^{13} \mathrm{C}$ & $\delta^{15} \mathrm{~N}$ & $\mathrm{C}: \mathrm{N}$ & $\%$ Collagen & $\% \mathrm{C}$ & $\% \mathrm{~N}$ \\
\hline Mostagedda & Cow (Bos spp.) & -13.7 & 9.3 & 3.2 & 4.2 & 24.9 & 9.1 \\
\hline Mostagedda & Cow (Bos spp.) & / & / & / & 0.0 & / & / \\
\hline Mostagedda & Sheep (Ovis aries) ${ }^{*}$ & -18.9 & 6.6 & 3.2 & 2.4 & 35.2 & 11.6 \\
\hline Mostagedda & Cow (Bos taurus) & -19.0 & 9.4 & 3.1 & 9.7 & 31.3 & 11.7 \\
\hline Mostagedda & Cow (Bos spp.) ${ }^{*}$ & -15.7 & 10.7 & 3.6 & 0.2 & 18.2 & 6.0 \\
\hline Mostagedda & Pig (Sus scrofa) & -20.9 & 7.8 & 3.1 & 11.5 & 32.8 & 12.2 \\
\hline Mostagedda & Equid (Equus spp.) & -20.5 & 4.3 & 3.1 & 8.5 & 30.9 & 11.7 \\
\hline Mostagedda & Striped Hyena (Hyaena hyaena) & -14.1 & 12.9 & 3.1 & 9.5 & 42.9 & 16.2 \\
\hline Mostagedda & Bovid (Bovidae spp.) & -19.9 & 7.9 & 3.1 & 0.7 & / & 1 \\
\hline Mostagedda & Camel (Camelus dromedarius) & -12.3 & 11.7 & 3.1 & 6.9 & 42.7 & 16.0 \\
\hline el-Badari & Sheep/Goat (Ovis aries/Capra hircus) & -18.9 & 6.8 & 3.2 & 0.3 & 46.6 & 17.2 \\
\hline el-Badari & Sheep/Goat (Ovis aries/Capra hircus) & / & / & / & 0.1 & / & 1 \\
\hline el-Badari & Sheep/Goat (Ovis aries/Capra hircus) & / & / & / & 0.1 & / & / \\
\hline el-Badari & Sheep/Goat (Ovis aries/Capra hircus) & / & / & / & 1.4 & / & / \\
\hline el-Badari & Cow (Bos taurus) & -15.8 & 9.5 & 3.5 & 12.4 & l & l \\
\hline el-Badari & Cow (Bos taurus) & -17.1 & 10.0 & 3.9 & 10.6 & 1 & / \\
\hline el-Badari & Cow (Bos taurus) & -18.9 & 6.8 & 3.2 & 0.8 & 33.1 & 12.2 \\
\hline el-Badari & Cow (Bos taurus) & / & 1 & / & 0.1 & / & 1 \\
\hline el-Badari & Cow (Bos taurus) & -13.1 & 12.0 & 3.2 & 6.6 & 29.9 & 10.8 \\
\hline el-Badari & Cow (Bos taurus) & -17.2 & 11.5 & 3.2 & 4.1 & 31.3 & 11.3 \\
\hline el-Badari & Cow (Bos taurus) & -16.3 & 11.5 & 3.2 & 2.8 & 32.2 & 11.7 \\
\hline el-Badari & Cow (Bos taurus) & -12.5 & 12.9 & 3.2 & 8.2 & 23.6 & 8.6 \\
\hline el-Badari & Cow (Bos taurus) & -13.1 & 11.6 & 3.2 & 2.2 & 30.5 & 11.2 \\
\hline el-Badari & Cow (Bos taurus) & -15.9 & 11.1 & 3.2 & 1.8 & 28.6 & 10.4 \\
\hline el-Badari & Ass (Equus asinus) & / & / & / & 0.2 & / & 1 \\
\hline el-Badari & Pig (Sus scrofa) & / & / & / & 0.1 & 1 & 1 \\
\hline el-Badari & Pig (Sus scrofa) & -17.6 & 9.7 & 3.2 & 5.4 & 18.1 & 6.6 \\
\hline Unknown (Petrie Collection) & Cow (Bos spp.) & -11.2 & 11.6 & 3.3 & 2.1 & 39.7 & 14.2 \\
\hline Unknown (Petrie Collection) & Ass (Equus asinus) & -16.8 & 12.9 & 3.1 & 0.2 & 59.6 & 22.7 \\
\hline Unknown (Petrie Collection) & Cow (Bos spp.) & / & / & / & 0.1 & / & 1 \\
\hline Unknown (Petrie Collection) & Cow (Bos spp.) & 1 & / & / & 0.6 & 1 & / \\
\hline Unknown (Petrie Collection) & Cow (Bos spp.) ${ }^{*}$ & / & / & / & 0.8 & / & / \\
\hline Unknown (Petrie Collection) & Cow $(\text { Bos spp. })^{*}$ & / & / & 1 & 0.0 & / & / \\
\hline Unknown (Petrie Collection) & East African Buffalo (Syncerus caffer) & -19.9 & 7.7 & 3.3 & 0.2 & 46.7 & 16.5 \\
\hline Unknown (Petrie Collection) & East African Buffalo (Syncerus caffer) ${ }^{*}$ & / & / & / & 0.0 & / & 1 \\
\hline Unknown (Petrie Collection) & Cow (Bos spp.) & / & / & / & 0.0 & / & / \\
\hline Unknown (Petrie Collection) & Cow (Bos spp.) & 1 & 1 & / & 0.1 & 1 & / \\
\hline Unknown (Petrie Collection) & Cow (Bos spp.) & / & / & / & 0.1 & / & / \\
\hline Unknown (Petrie Collection) & Cow (Bos spp.) & / & / & / & 0.1 & / & / \\
\hline Unknown (Petrie Collection) & Cow (Bos spp.) & / & / & / & 0.1 & 1 & / \\
\hline Unknown (Petrie Collection) & Cow (Bos spp.) & / & / & / & 0.4 & / & l \\
\hline Lahun & Cow (Bos spp.) & / & / & / & 0.3 & / & / \\
\hline Lahun & Cow (Bos spp.) & / & / & / & 0.6 & / & / \\
\hline Unknown (Petrie Collection) & Cow (Bos spp.) & -26.5 & 1 & 4.8 & 0.2 & 86.4 & 21.2 \\
\hline Unknown (Petrie Collection) & Cow (Bos spp.) & -19.0 & 5.3 & 5.0 & 1.8 & 6.8 & 1.6 \\
\hline Unknown (Petrie Collection) & Turtle (Testudinidae) & / & / & / & 0.1 & 1 & / \\
\hline Unknown (Petrie Collection) & Cow (Bos taurus) & -14.0 & 4.4 & 3.1 & 0.1 & 55.7 & 20.7 \\
\hline Unknown (Petrie Collection) & Hartebeest (Alceleophus bucelaphus)* & -16.2 & 15.6 & 3.2 & 5.6 & 43.7 & 16.2 \\
\hline Unknown (Petrie Collection) & Hartebeest (Alceleophus bucelaphus) ${ }^{*}$ & -17.0 & 12.3 & 3.1 & 8.0 & 42.6 & 15.9 \\
\hline Unknown (Petrie Collection) & Nile Perch (Lates niloticus) & -14.9 & 5.0 & 3.5 & 3.0 & 42.0 & 13.9 \\
\hline Unknown & Pig (Sus spp.) & / & / & / & 0.2 & / & 1 \\
\hline Unknown & Cow (Bos spp.) & / & / & / & 0.1 & / & / \\
\hline Kharga Oasis & Cow (Bos spp.) & -8.9 & 10.7 & 3.2 & 1.0 & 41.7 & 15.4 \\
\hline Kharga Oasis & Cow (Bos spp.) & / & / & / & 0.0 & / & 1 \\
\hline Kharga Oasis & Cow (Bos spp.) & l & 1 & / & 0.0 & / & l \\
\hline Kharga Oasis & Cow (Bos spp.) & / & / & / & 0.0 & 1 & / \\
\hline Unknown & Sheep (Ovis aries) ${ }^{*}$ & -19.5 & 6.7 & 3.2 & 4.9 & 42.5 & 17.4 \\
\hline Unknown & Hyena (Hyaenidae spp.) & -15.7 & 12.8 & 3.2 & 6.7 & 44.2 & 14.9 \\
\hline Lahun & Cow (Bos spp.) & / & / & / & 0.0 & / & 1 \\
\hline Lahun & Cow (Bos spp.) & 1 & / & / & 0.3 & 1 & / \\
\hline Qau & Cow (Bos spp.) & -19.8 & 9.3 & 3.3 & 0.1 & 28.5 & 10.2 \\
\hline Qau & Dog (Canis spp.) & -18.3 & 9.0 & 3.4 & 4.5 & 27.7 & 8.7 \\
\hline Qau & Dog (Canis spp.) & -17.7 & 5.9 & 3.4 & 7.3 & 38.8 & 12.2 \\
\hline Qau & Cow (Bos spp.) & -17.6 & 6.0 & 3.3 & 5.6 & 17.7 & 6.4 \\
\hline
\end{tabular}




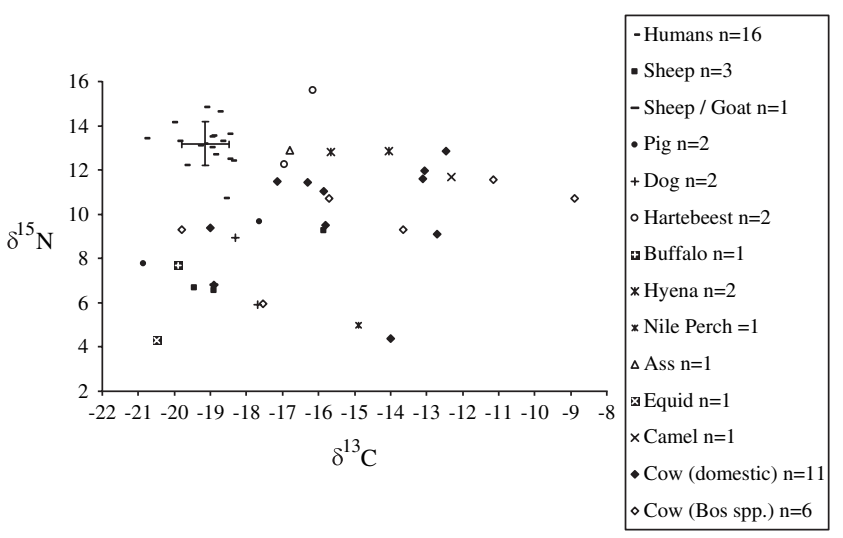

Fig. 2. Plot of isotopic data measured from bone collagen extracted from human and faunal samples (SD of human samples shown with bars).

effects causing ${ }^{15} \mathrm{~N}$ enrichment observed in rats under protein, water and heat stress [4].

\subsection{Domesticated animals}

Isotopic measurements of cattle collagen samples indicate the consumption of resources with the broadest isotopic range of any of the species analysed, both for those identified specifically as domestic cattle and those only identified generally as Bos. The cattle population as a whole has $\delta^{13} \mathrm{C}$ values that are quite distinct from the human population (see Fig. 2), indicating that the humans analysed in this study did not generally consume these cattle or products derived from them (e.g. milk or blood) in any significant quantity. It is worth noting the oxen-burial context of some of these samples, perhaps indicating that these specially interred animals were primarily used for purposes other than for food.

The cattle samples from the Nile Valley sites of Mostagedda, el-Badari and Qau have a very broad

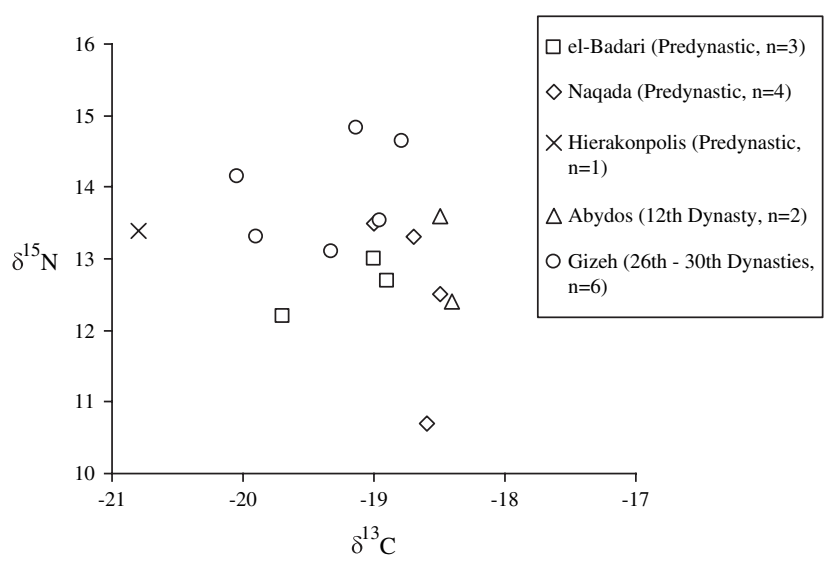

Fig. 3. Plot of isotopic measurements from bone collagen extracted from human samples from Egyptian Nile Valley sites.

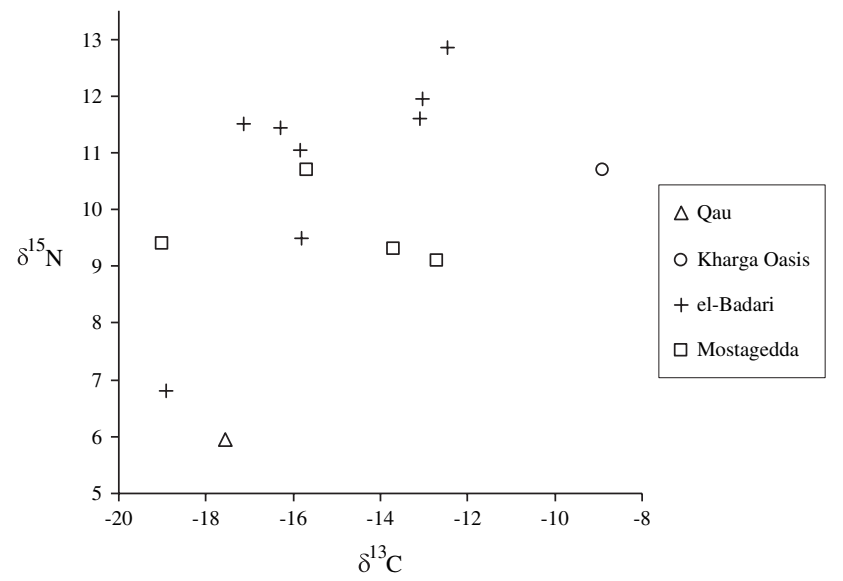

Fig. 4. Plot of isotopic data measured from cattle bone collagen samples.

range of $\delta^{13} \mathrm{C}$ values both across the whole population, ranging from $-19 \%$ to $-12.5 \%$ and within the site populations, ranging from -18.9 to -12.5 for the el-Badari cattle and $-19 \%$ to $-12.7 \%$ for the Mostagedda population (Fig. 4). The range in $\delta^{15} \mathrm{~N}$ values is also considerable, from $6.0 \%$ to $12.9 \%$. It is clear then that these cattle came from, or at least consumed their food, in very different ecological contexts. Therefore, these differences could be explained by a variety of herding strategies being employed at the two sites, giving access to differing proportions of $\mathrm{C}_{3}$ and $\mathrm{C}_{4}$ plant foods depending on the area where they were grazed. This is supported by the observation that there is a general trend for the cattle with the highest $\delta^{15} \mathrm{~N}$ values to have the most enriched $\delta^{13} \mathrm{C}$ values, potentially indicating grazing further out towards the desert margin by these individuals.

Another possible explanation is not all of the cattle having originated at the sites from which they were excavated. The marshy Nile delta region was known as a region where animal herds were sent to graze from the south [10], which could account for the differences in isotopic values within the samples we measured. Similar isotopic variations have been observed at other Near Eastern sites when cattle and sheep were compared, and were interpreted as being due to differing herding strategies between species [7,43].

The cattle sample from the Kharga Oasis indicates different feeding habits to those from the Nile Valley, with a very enriched $\delta^{13} \mathrm{C}$ value of $-8.9 \%$, possibly due to the consumption of sorghum or millet by this individual. A value of approximately $-6.5 \%$ would be expected in the Nile Valley for an individual consuming a pure $\mathrm{C}_{4}$-based diet [58], so $-8.9 \%$ indicates a significant intake of $\mathrm{C}_{4}$ plants.

Ovicaprids are commonly found on excavations and were kept for meat, milk and hair [10]. The ovicaprids analysed here have more of a $\mathrm{C}_{3}$-based diet than the 
cattle and have less elevated $\delta^{15} \mathrm{~N}$ values, suggesting that they were not as likely to have regularly consumed plants from arid ${ }^{15} \mathrm{~N}$ enriched soil at the edge of the desert. Single individuals analysed from el-Badari, Mostagedda and an unprovenanced individual lie together on the plot, with one sheep from Mostaggedda showing more $\mathrm{C}_{4}$ input $\left(\delta^{13} \mathrm{C}=-15.9 \%\right.$ ) and a more elevated $\delta^{15} \mathrm{~N}$ value $(9.3 \%$ ) than the others.

The two Sus samples analysed have quite different $\delta^{13} \mathrm{C}$ values, with one individual consuming an almost exclusively $\mathrm{C}_{3}$ diet; the $\delta^{13} \mathrm{C}$ value of $-20.9 \%$ close to the $-21 \%$ expected for a pure $\mathrm{C}_{3}$ diet (based on a value of $-26 \%$ for $\mathrm{C}_{3}$ plants assuming a $5 \%$ enrichment). The $\delta^{13} \mathrm{C}$ value of the other Sus $(-17.6 \%)$ indicates some $\mathrm{C}_{4}$ input to the diet and the higher $\delta^{15} \mathrm{~N}$ value possibly indicates consumption of food from a different trophic level or environment.

One of the equids analysed was identified as an ass, and has differing isotopic values to the other, which was only identified to species. This latter individual shows a very negative $\delta^{13} \mathrm{C}$ value and a low $\delta^{15} \mathrm{~N}$ value whilst the ass shows a less negative $\delta^{13} \mathrm{C}$ value and a much higher $\delta^{15} \mathrm{~N}$ value. Isotopically these animals look as if they may have lived in contrasting environments; the first individual resembling a temperate equid, whilst the second has a $\delta^{13} \mathrm{C}$ value indicating some $\mathrm{C}_{4}$ input into the diet and a high $\delta^{15} \mathrm{~N}$ value suggesting an effect of the global ${ }^{15} \mathrm{~N}$ enrichment seen in arid regions such as the Nile valley environs [47]. As with many of the species examined here, a larger study of equids from the region would be interesting to establish where a "typical" equid might be expected to lay on the plot.

The dogs analysed here are both from the site of Qau and have lower $\delta^{15} \mathrm{~N}$ values than we might predict for a largely carnivorous species. The $\operatorname{dog} \delta^{15} \mathrm{~N}$ values are comparable to two cattle samples from the same context, and indeed the dog with the lowest $\delta^{15} \mathrm{~N}$ is virtually isotopically indistinguishable from some of the cattle. This is explained by either the dogs having a largely plant-based diet, which is probably unlikely, or due to the dogs sampling a different ecosystem than the cattle, possibly as they were from different temporal or spatial contexts.

The camel we sampled is most likely domesticated, as domestic camels were introduced into Egypt relatively late [29] and this individual was radiocarbon dated to $730 \pm 160$ BC (OXA-964). This animal had a large $C_{4}$ plant component in its diet and also has a raised $\delta^{15} \mathrm{~N}$ value, indicating that the plants consumed were likely from a very arid area, as expected.

\subsection{Wild fauna}

Hartebeest are no longer present in North Africa and so the data from these samples is of particular interest
[38]. They are included here as wild animals even though it is thought that there were attempts to domesticate them by Dynastic Egyptian populations [38]. The isotopic values suggest that these individuals were consuming a significant proportion of $\mathrm{C}_{4}$ plant foods in their diet, mixed in with some $\mathrm{C}_{3}$ input. One of these individuals shows the highest $\delta^{15} \mathrm{~N}$ values of any sample analysed, higher even than the hyenas discussed below. This could indicate that these animals were grazing plants from the extremely water deprived areas in the desert and affected by the elevated ${ }^{15} \mathrm{~N}$ content of the soil. However, hartebeest are also noted as being extremely tolerant of poor-quality fodder [36], and so may be ${ }^{15} \mathrm{~N}$-enriched due to protein stress [50]. Data from the buffalo, another grazing species no longer seen as far north as Egypt [21], contrast with the hartebeest values, with much less enriched $\delta^{15} \mathrm{~N}$ and $\delta^{13} \mathrm{C}$ values, likely reflecting the consumption of plants from closer to the Nile.

Hyena isotopic values were measured to provide isotopic values for top-level carnivores in this region, as despite being scavengers, hyenas will generally only consume animal products [38]. It can be seen from Fig. 2, the hyenas had very high $\delta^{15} \mathrm{~N}$ values, reflecting their trophic position, and the $\delta^{13} \mathrm{C}$ values indicate that they were feeding on animals which themselves had a significant $\mathrm{C}_{4}$ input into their diet.

The Nile perch $\delta^{15} \mathrm{~N}$ value is surprising for a piscivore, being only $5 \%$, which is much lower than the value expected [9], and different from the isotopic values reported for modern freshwater fish from Lake Nassar [27]. The recovery of large quantities of fish bone from archaeological sites along the Nile valley and textual evidence of fish consumption indicate that fish was a major natural resource in antiquity [32]. However, it is not possible that fish with these isotopic values made any significant protein contribution to the diet of the humans we measured, as the $\delta^{15} \mathrm{~N}$ value is far too low, and the $\delta^{13} \mathrm{C}$ value at $-14.9 \%$ is much more positive than the humans. Of course, isotopic evidence from a single bone, the ecological and geographical context of which is not known, is not adequate and a larger sample is being sought.

\subsection{Diet of the human population (Table 2)}

The isotopic values from the humans are tightly clustered, with mean $\delta^{13} \mathrm{C}$ values of $-19.1 \pm 0.7 \%$ and mean $\delta^{15} \mathrm{~N}$ values of $13.2 \pm 1.0 \%$, values which are broadly similar to Egyptian human isotope values presented elsewhere $[20,26,33,47]$. The human average $\delta^{13} \mathrm{C}$ values can best be interpreted as indicating a diet with protein sources from $\mathrm{C}_{3}$ plants, and perhaps fauna that consumed $\mathrm{C}_{3}$ plants. There does not seem to be any significant input of $\mathrm{C}_{4}$ protein, either plant or animal derived. 
A significant problem with any comprehensive interpretation of the human data is that the fauna we measured do not necessarily come from the same sites and time periods as the humans, which is an unavoidable problem with material from this region. The human $\delta^{15} \mathrm{~N}$ values are high, especially compared to the faunal isotopic values we present here. As discussed earlier this is likely due to the consumption of protein from animals that consumed plants from arid contexts which have elevated $\delta^{15} \mathrm{~N}$ values. However, pinpointing the main dietary protein source is particularly difficult in this context, as there are no obvious candidates from the associated fauna we measured. We believe the best possible explanation for the human values is the consumption of animal protein from species and ecosystems that we did not sample here. A likely candidate for this may be freshwater fish, although our single perch sample did not have isotopic values that could explain the human values. Isotopic values of three modern perch from Egypt, as reported in Iacumin et al. [27] are possible candidates for explaining the human values, with average isotopic values of $\delta^{13} \mathrm{C}=-17.9 \%$ and $\delta^{15} \mathrm{~N}=11.9 \%$. Based upon the cattle isotopic data presented here, which was very scattered, we could conclude that the humans did not consume any significant amounts of protein from beef and/or cattle milk derived products. However, we must emphasise that these are preliminary interpretation of our data and further comparisons of directly comparable samples, both temporally and geographically, are needed.

\section{Summary and conclusions}

The results indicate a complex picture of human and animal diet in the Egyptian Nile Valley and the surrounding area, which contains multiple ecological niches and ecosystems. The human population appears to have been consuming a largely $\mathrm{C}_{3}$-based diet, with elevated $\delta^{15} \mathrm{~N}$ values, which are not easily explained through comparison to the faunal data we measured, but may possibly be due to the consumption of freshwater fish from the Nile. No clear patterns are present to suggest dietary differences through time, and the overall homogeneity of the group is striking.

Future work on a larger human population sample and possibly the use of a third source of isotopic information such as sulphur (e.g. [42]) may provide a fuller picture of dietary changes through time, enabling a clearer distinction between dietary and environmental information to be made.

This paper was intended to contribute a significant amount of new faunal and human isotopic data from Egypt. The complexity of the isotopic data is fascinating, and clearly further research, especially on directly comparable human and fauna, needs to be undertaken to better understand the isotope ecology of Ancient Egypt.

\section{Acknowledgements}

We are grateful to Richard Sabin, Natural History Museum, London and Marta Lahr, Rob Foley and Maggie Bellati, Duckworth Collection, Cambridge, for allowing access to material in their collections. We would also like to thank Gundula Müldner for helpful comments on the paper and we would also like to thank Heléne le Cordier and Ken Neal for assistance in sample preparation and measurement.

\section{References}

[1] S.H. Ambrose, Preparation and characterisation of bone and tooth collagen for stable isotopic analysis, Journal of Archaeological Science 17 (1990) 431-451.

[2] S.H. Ambrose, Effects of diet, climate and physiology on nitrogen isotope abundances in terrestrial foodwebs, Journal of Archaeological Science 18 (1991) 293-317.

[3] S.H. Ambrose, Isotopic analysis of palaeodiets: methodological and interpretive considerations, in: K. Sandford (Ed.), Investigations of Ancient Human Tissues: Chemical Analyses in Anthropology, Gordon and Breach, Langhorne, PA, 1993, pp. 1-37.

[4] S.H. Ambrose, Controlled diet and climate experiments on nitrogen isotope ratios of rat bone collagen, hair and muscle, in: S.H. Ambrose, M.A. Katzenberg (Eds.), Biogeochemical Approaches to Paleodietary Analysis, Kluwer Academic/Plenum Publishers, New York, 2000, pp. 243-259.

[5] H. Bocherens, M. Fizet, A. Mariotti, B. Lange-Badre, B. Vandermeersch, J.P. Borel, G. Bellon, Isotopic biogeochemistry $\left({ }^{13} \mathrm{C},{ }^{15} \mathrm{~N}\right)$ of fossil vertebrate collagen: application to the study of a past food web including Neanderthal man, Journal of Human Evolution 20 (1991) 481-492.

[6] H. Bocherens, M.L. Fogel, N. Tuross, M. Zeder, Trophic level structure and climatic information from isotopic signatures in Pleistocene cave fauna of southern England, Journal of Archaeological Science 22 (1995) 327-340.

[7] H. Bocherens, M. Mashkour, D. Billiou, Palaeoenvironmental and archaeological implications of isotopic analyses $\left({ }^{13} \mathrm{C},{ }^{15} \mathrm{~N}\right)$ from Neolithic to Present in Qazvin Plain (Iran), Environmental Archaeology 5 (2000) 1-19.

[8] H. Bocherens, D. Drucker, Trophic level isotopic enrichment of carbon and nitrogen in bone collagen: case studies from recent and ancient terrestrial ecosystems, International Journal of Osteoarchaeology 13 (2003) 46-53.

[9] D. Brewer, Temperatures in Predynastic Egypt inferred from the remains of the Nile Perch, World Archaeology 22 (3) (1991) 288-303.

[10] D.J. Brewer, D.B. Redford, S. Redford, Domestic Plants and Animals: The Egyptian Origins, Aris \& Philips, Warminster, 1998.

[11] T.A. Brown, D.E. Nelson, J.R. Southon, Improved collagen extraction by a modified Longin method, Radiocarbon 30 (1988) 171-177.

[12] G. Brunton, G. Caton-Thompson, The Badarian Civilisation and Predynastic Remains Near Badari, London, British School of Archaeology in Egypt, 1928. 
[13] G. Brunton, Mostagedda and the Tasian Culture, London: Quaritch, British Museum Expedition to Middle Egypt, first and second years 1928, 1929, 1937.

[14] K.W. Butzer, Early Hydraulic Civilization in Egypt, University of Chicago Press, Chicago, IL, 1976.

[15] B. Chisholm, D.E. Nelson, H.P. Schwarcz, Stable carbon ratios as a measure of marine versus terrestrial protein in ancient diets, Science 216 (1982) 1131-1132.

[16] W.J. Darby, P. Ghaloiungui, L. Grivetti, Food: The Gift of Osiris, New York, San Francisco, Academic Press, London, 1977.

[17] M.J. DeNiro, Post-mortem preservation and alteration of in vivo bone collagen isotope ratios in relation to palaeodietary reconstruction, Nature 317 (1985) 806-809.

[18] E. Dufour, H. Bocherens, A. Mariotti, Palaeodietary implications of isotopic variability in Eurasian Lacustrine fish, Journal of Archaeological Science 26 (1999) 617-627.

[19] T. Dupras, H.P. Schwarcz, Strangers in a strange land: stable isotope evidence for human migration in the Dakhleh Oasis, Egypt, Journal of Archaeological Science 28 (2001) 1199-1208.

[20] T.L. Dupras, H.P. Schwarcz, S.I. Fairgrieve, Infant feeding and weaning practices in Roman Egypt, American Journal of Physical Anthropology 115 (2001) 204-212.

[21] R. Estes, The Behaviour Guide to African Mammals, University of California Press, Berkeley, CA, 1991.

[22] M. Fizet, A. Mariotti, H. Bocherens, B. Lange-Badre, B. Vandermeersch, J.P. Borel, G. Bellon, Effect of diet, physiology and climate on carbon and nitrogen stable isotopes of collagen in a Late Pleistocene anthropic system: Marillac, Charente, France, Journal of Archaeological Science 22 (1995) 67-79.

[23] J.R. Geller, From prehistory to history: beer in Egypt, in: R. Friedman, B. Adams (Eds.), The Followers of Horus: Studies Dedicated to Michael Allen Hoffman 1944-1990, Egyptian Studies Association Publication 2, Oxbow Monograph 20, Oxbow, Oxford, 1992, pp. 19-26.

[24] D.R. Grocke, H. Bocherens, A. Mariotti, Annual rainfall and nitrogen-isotope correlation in macropod collagen: application as a palaeoprecipitation indicator, Earth and Planetary Science Letters 153 (1997) 279-285.

[25] T.H.E. Heaton, J.C. Vogel, G. von la Chevallerie, G. Collet, Climatic influence on the isotopic composition of bone nitrogen, Nature 322 (1986) 822-823.

[26] P. Iacumin, H. Bocherens, A. Mariotti, A. Longinelli, An isotopic palaeoenvironmental study of human skeletal remains from the Nile Valley, Palaeogeography, Palaeoclimatology, Palaeoecology 126 (1996) 15-30.

[27] P. Iacumin, H. Bocherens, L. Chaix, A. Mariotti, Stable carbon and nitrogen isotopes as dietary indicators of ancient Nubian populations (Northern Sudan), Journal of Archaeological Science 25 (1998) 293-301.

[28] S. Ikram, Meat processing, in: P.T. Nicholson, I. Shaw (Eds.), Ancient Egyptian Materials and Technology, Cambridge University Press, Cambridge, 2000, pp. 656-671.

[29] R. Janssen, J. Janssen, Egyptian Household Animals, Shire Publications, Aylesbury, London, 1989.

[30] M.A. Katzenberg, S. Pfeiffer, Stable isotope analysis: a tool for studying past diet, demography and life history, in: M.A. Katzenberg, S.R. Saunders (Eds.), Biological Anthropology of the Human Skeleton, Wiley-Liss, New York, 2000, pp. 305-328.

[31] B.J. Kemp, D. Samuel, R. Luff, Feeding an Egyptian city: tell el-Amarna, in: P. Rowley-Conwy, R. Luff (Eds.), Whither Environmental Archaeology? Oxford University Press, Oxford, 1994, pp. 133-170.

[32] R.M. Luff, G. Bailey, The aquatic basis of ancient civilisations: the case of the Synodontis schall and the Nile Valley, in: G. Bailey, R. Charles, N. Winder (Eds.), Human Ecodynamics, Oxbow Books, Oxford, 1998, pp. 100-113.
[33] S.A. Macko, M.H. Engel, V. Andrusevich, G. Lubec, T.C. O'Connell, R.E.M. Hedges, Documenting diet in ancient human populations through stable isotope analysis of hair, Philosophical Transactions of the Royal Society of London, Series B 354 (1999) 65-76.

[34] S. Mays, New directions in the analysis of stable isotopes in excavated bones and teeth, in: M. Cox, S. Mays (Eds.), Human Osteology in Archaeology and Forensic Science, Greenwich Medical Media, London, 2000, pp. 425-438.

[35] K.M. Moore, M.L. Murray, M.J. Schoeninger, Dietary reconstruction from bones treated with preservatives, Journal of Archaeological Science 16 (1989) 437-446.

[36] M. Murray, Comparative nutrition of wildebeest, hartebeest and topi in the Serengheti, African Journal of Ecology 31 (1993) 172-177.

[37] M.A. Murray, Cereal production and processing, in: P.T. Nicholson, I. Shaw (Eds.), Ancient Egyptian Materials and Technology, Cambridge University Press, Cambridge, 2000, pp. 505-536.

[38] D.J. Osborn, J. Osbornova, The Mammals of Ancient Egypt, Aris \& Philips, Warminster, 1998.

[39] M.P. Richards, P.A. Mellars, Stable isotopes and the seasonality of the Oronsay middens, Antiquity 72 (1998) 178-184.

[40] M.P. Richards, R.E.M. Hedges, Stable isotope evidence for similarities in the types of marine foods used by Late Mesolithic humans at sites along the Atlantic coast of Europe, Journal of Archaeological Science 26 (1999) 717-722.

[41] M.P. Richards, R.E.M. Hedges, R. Jacobi, A. Current, C. Stringer, Gough's Cave and Sun Hole Cave: human stable isotope values indicate a high animal protein diet in the British Upper Palaeolithic, Journal of Archaeological Science 27 (2000) 1-3.

[42] M.P. Richards, B.T. Fuller, R.E.M. Hedges, Sulphur isotopic variation in ancient bone collagen from Europe: implications for human palaeodiet, residence mobility and modern pollutant studies, Earth and Planetary Science Letters 191 (2001) 185-190.

[43] M.P. Richards, J.A. Pearson, T.I. Molleson, N. Russell, L. Martin, Stable isotope evidence of diet at Neolithic Catalhoyuk, Turkey, Journal of Archaeological Science 30 (2003) 67-76.

[44] M. Schoeninger, M.J. DeNiro, Nitrogen and carbon isotopic composition of bone collagen from marine and terrestrial animals, Geochimica and Cosmochimica Acta 48 (1984) 625-639.

[45] M.J. Schoeninger, M.J. DeNiro, H. Tauber, Stable nitrogen isotope ratios of bone collagen reflect marine and terrestrial components of prehistoric human diet, Science 220 (1983) 13811383.

[46] M.J. Schoeninger, Stable isotope studies in human evolution, Evolutionary Anthropology 4 (1995) 83-98.

[47] H.P. Schwarcz, T.L. Dupras, S.I. Fairgrieve, ${ }^{15} \mathrm{~N}$ enrichment in the Sahara: in search of a global relationship, Journal of Archaeological Science 26 (1999) 629-636.

[48] H.P. Schwarcz, C.D. White, The grasshopper or the ant? cultigenuse strategies in ancient Nubia from C-13 analyses of human hair, Journal of Archaeological Science 31 (2004) 753-762.

[49] J. Sealy, Body tissue chemistry and palaeodiet, in: D.R. Brothwell, A.M. Pollard (Eds.), Handbook of Archaeological Sciences, John Wiley \& Sons, Chichester, 2001, pp. 269-279.

[50] J.C. Sealy, N.J. van der Merwe, J.A. Lee Thorp, J.L. Lanham, Nitrogen isotope ecology in southern Africa: implications for environmental and dietary tracing, Geochimica and Cosmochimica Acta 51 (1987) 2707-2717.

[51] C.I. Smith, A.T. Chamberlain, M.S. Riley, A. Cooper, C.B. Stringer, M.J. Collins, Not just old but old and cold? Nature 410 (2001) 771-772.

[52] M. Sponheimer, T. Robinson, L. Ayliffe, B. Roeder, J. Hammer, B. Passey, A. West, T. Cerling, D. Dearing, J. Ehleringer, Nitrogen isotopes in mammalian herbivores: hair $\delta^{15} \mathrm{~N}$ values 
from a controlled feeding study, International Journal of Osteoarchaeology 13 (2003) 80-87.

[53] M.J. Stenhouse, M.S. Baxter, The uptake of bomb ${ }^{14} \mathrm{C}$ in humans, in: R. Berger, H. Suess (Eds.), Radiocarbon Dating, University of California Press, Berkeley, CA, 1979, pp. 324-341.

[54] F. Wendorf, A.E. Close, Early Neolithic food-economies in the Eastern Sahara, in: R. Friedman, B. Adams (Eds.), The Followers of Horus: Studies Dedicated to Michael Allen Hoffman 1944 1990, Egyptian Studies Association Publication 2, Oxbow Monograph 20, Oxbow, Oxford, 1992, pp. 155-162.

[55] W. Wetterstrom, Foraging and farming in Egypt: the transition from hunting and gathering to horticulture in the Nile Valley, in: T. Shaw, P. Sinclair, B. Audah, A. Okpolio (Eds.), The Archaeology of Africa: Food, Metals and Towns, Routledge, 1993, pp. 165-226.

[56] C. White, F.J. Longstaffe, K.R. Law, Exploring the effects of environment, physiology and diet on oxygen isotope ratios in ancient Nubian bones and teeth, Journal of Archaeological Science 31 (2004) 233-250.
[57] C.D. White, Isotopic determination of seasonality in diet and death from Nubian mummy hair, Journal of Archaeological Science 20 (1993) 657-666.

[58] C.D. White, H.P. Schwarcz, Temporal trends in stable isotopes for Nubian mummy tissues, American Journal of Physical Anthropology 93 (1994) 165-187.

[59] C.D. White, F. Longstaffe, K. Law, Isotopic analysis of hair and skin from Kharga Oasis mummies, Unpublished Report to the American Museum of Natural History, 1995.

[60] C.D. White, G.J. Armelagos, Osteopenia and stable isotope ratios in bone collagen of Nubian female mummies, American Journal of Physical Anthropology 103 (1997) 185-199.

[61] C.D. White, F. Longstaffe, K. Law, Seasonal stability and variation in diet as reflected in human mummy tissues from the Kharga Oasis and the Nile Valley, Palaeogeography, Palaeoclimatology, Palaeoecology 147 (1999) 209-222.

[62] H. Wilson, Egyptian Food and Drink, Shire Publications, 1988. 